\title{
Iatrogenic Major Vascular Injury During Lumbar Discectomy: Report of Three Cases
}

\author{
Lomber Disk Cerrahisi Strasında Iyatrojenik Damar Yaralanmaları: \\ $\ddot{U}_{c}$ Olgunun Sunumu
}

\author{
Metin KESKIN, Kursat Rahmi SERIN, Fatih Ata GENC, Murat AKSOY, Fatih YANAR, Mehmet KURTOGLU \\ Istanbul University, Istanbul Faculty of Medicine, Department of General Surgery, Fatih, Istanbul, Turkey
}

Corresponding Author: Metin KESKIN / E-mail: mtnkeskin@yahoo.com

\begin{abstract}
latrogenic vascular injury rarely occurs during lumbar disc surgery and can be fatal if it is not recognized instantly. In this paper we aim to introduce three iatrogenic vascular injuries that occurred during the lumbar disc surgery. The first case was consulted because of the sudden hypotension attack during lumbar disc surgery. The left common iliac artery and bilateral common iliac vein injuries were detected in emergency laparotomy, and repaired primarily. The second case was consulted to our clinic because of the hypotension attack at the first postoperative day. Left common iliac artery and vein injuries were diagnosed by CT angiography. Left common iliac vein was ligated and left common iliac arterial injury was repaired primarily by laparotomy. The third case was referred to our clinic for left lower extremity ischemia. Left common iliac artery injury was diagnosed by simple physical examination. Reconstruction by PTFE graft interposition was performed. The first patient died due to disseminated intravascular coagulation at the early postoperative period. Pulmonary embolus developed in the iliac vein ligated patient but was well treated by anticoagulant therapy. The last patient was discharged without any problem. Two of the patients are well on long-term follow-up.
\end{abstract}

KEYWORDS: Discectomy, Vascular injury, Reconstruction, Ven ligation

\section{öz}

Lomber disk cerrahisi sırasında iyatrojenik damar yaralanmaları, ender görülen ve geç fark edildiğinde mortaliteye neden olabilen bir komplikasyondur. Bu yazımızda, lomber fıtık disk cerrahisi esnasında oluşan iyatrojenik damar yaralanması nedeniyle ameliyat ettiğimiz üç olguyu sunmayı amaçladık. İlk olgu lomber herniektomi girişimi sırasında gelişen ani hipotansiyon nedeniyle konsülte edildi. Tanısal laparotomide sol ana iliak arter yaralanması, bilateral ana iliak ven yaralanması tespit edildi ve primer tamir yapıldı. Ameliyat sonrası (AS) birinci günde gelişen hipotansiyon nedeniyle kliniğimize sevk edilen ikinci olguda sol ana iliak arter ve ven yaralanması saptandı. Ana iliak ven ligasyonu ve ana iliak artere primer tamir yapıldı. Alt ekstremitede iskemik bulgular nedeniyle kliniğimize sevk edilen üçüncü olguda da sol ana iliak arter yaralanması saptayarak, kısmi arter rezeksiyonu ve PTFE (politetrafloretilen) greft interposizyonu uygulandı. Illk hasta ameliyat sonrası erken dönemde dissemine intravasküler koagulasyon nedeniyle kaybedilirken, diğer iki hasta ise şifa ile taburcu edildi.

ANAHTAR SÖZCÜKLER: Diskektomi, Damar yaralanması, Rekonstrüksiyon, Ven ligasyonu

\section{INTRODUCTION}

latrogenic vascular injury during lumber discectomy ranges from about 0.01 to $0.1 \%(13,4,12,18,9)$, but it is a lifethreatening complication $(3,4,12)$. Major vascular injury can lead to retroperitoneal hematoma, hypovolemic shock or lower extremity ischemia in the early postoperative period. If it is asymptomatic or cannot be identified, it can present with arteriovenous fistula (AVF) or pseudoaneurysm in the late postoperative period $(1,3,4,12,13)$. In this paper, we discussed three cases that were emerged for iatrogenic vascular injury during lumbar discectomy.

\section{CASE REPORTS}

\section{Case 1}

A 20-year-old female patient was consulted for hypotension and tachycardia attack after the earliest period of lumber herniectomy. Peroperative blood pressure was measured $70 / 30 \mathrm{mmHg}$, pulse rate was $116 /$ per minute. Emergency laparotomy was performed on vascular injury pre-diagnosis. $2000 \mathrm{cc}$ hemorrhagic fluid was seen in the abdomen. Left common iliac and bilateral common iliac vein injury was seen. All vascular injuries were repaired primarily. Totally 12 units of erythrocyte suspension was transfused. Unfortunately, patient was died at the early postoperative period due to disseminated intravascular coagulation, which was related to massive blood transfusion.

\section{Case 2}

Thirty-two years old male patient was consulted for dizziness and weakness on the $20^{\text {th }}$ hour of lumbar discectomy. Blood pressure was measured $90 / 40 \mathrm{mmHg}$ and pulse rate was 
104/per minute. Ankle brachial index was measured 0.9 at the left lower extremity. Hematocrit level was detected $29 \%$ and hemoglobin level was $9 \mathrm{~g} / \mathrm{dl}$. Free fluid was seen in the abdominal ultrasound. CT Angiography showed the contrast extravasation from the left common iliac artery (Figure 1). Left common iliac artery and vein injuries were detected in emergency laparotomy. Left iliac vein was ligated and artery was repaired primarily. Sudden respiratory distress was developed on the third day of the operation. Thorax $\mathrm{CT}$ angiography, ventilation-perfusion scintigraphy and echocardiography confirmed the pulmonary embolus. Required treatment was held. The patient was discharged without any problem under anticoagulation therapy. He is well at the $5^{\text {th }}$ year of the operation.

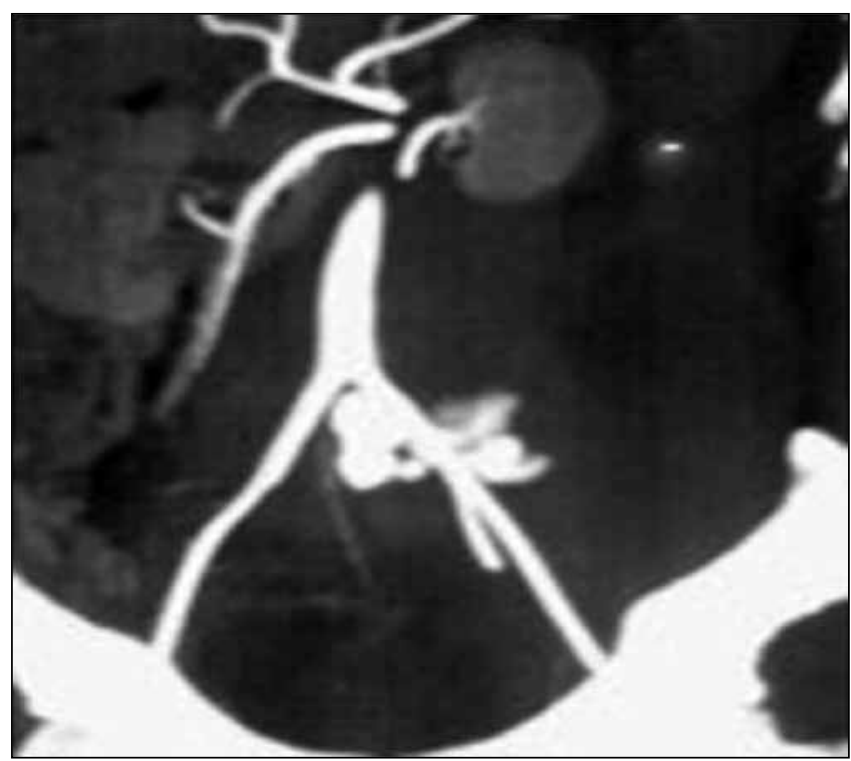

Figure 1: Contrast extravasation from the left common iliac artery.

\section{Case 3}

Forty-five years old female patient was consulted for pallor and coldness of left leg at the sixth hour of lumbar discectomy. In her physical examination, left lower extremity was cold and pale, and distal pulse was not palpable. Ankle brachial index was measured 0.3 at the left lower extremity. Hematocrit was measured 35\% and hemoglobin level was $11 \mathrm{~g} / \mathrm{dl}$. The patient underwent surgery with the suspicion of possible iatrogenic vascular injury. Left common iliac artery injury was seen and repaired by PTFE graft interposition (Figure 2A, B). On the second day of the operation, sudden respiratory distress was developed without any arterial complication. Bilateral lower extremity venous duplex US, echocardiography, ventilationperfusion scintigraphy, thorax CT were all in normal range and pulmonary embolus was excluded. Respiratory distress was regressed spontaneously on the follow-up and patient was discharged without any problem on the $12^{\text {th }}$ day of the operation. She is well at the $4^{\text {th }}$ year of the operation.

\section{DISCUSSION}

Vascular injury during lumbar discectomy is a serious and life-threatening complication. It is seen rarely because lumbar discectomy is performed from the posterior side as microdiscectomy and, bone and fibrous tissues lay between the operation field and vascular structures $(3,9,18)$. But degenerative process of anterior longitudinal ligament and annulus fibrosus, adhesions caused by previous discectomy or abdominal surgical procedure, patient position during surgery and pillow placement under abdominal region can increase vascular injury risk $(3,4,12,18)$.

Abdominal distension, pulsatile hemorrhage on the operation field, weakness, vertigo, nausea and vomiting, lack of pulse on the extremity and at last hypovolemic shock can be seen in the acute period. If it is asymptomatic or not diagnosed at the early period, it can present with arteriovenous fistula (AVF),

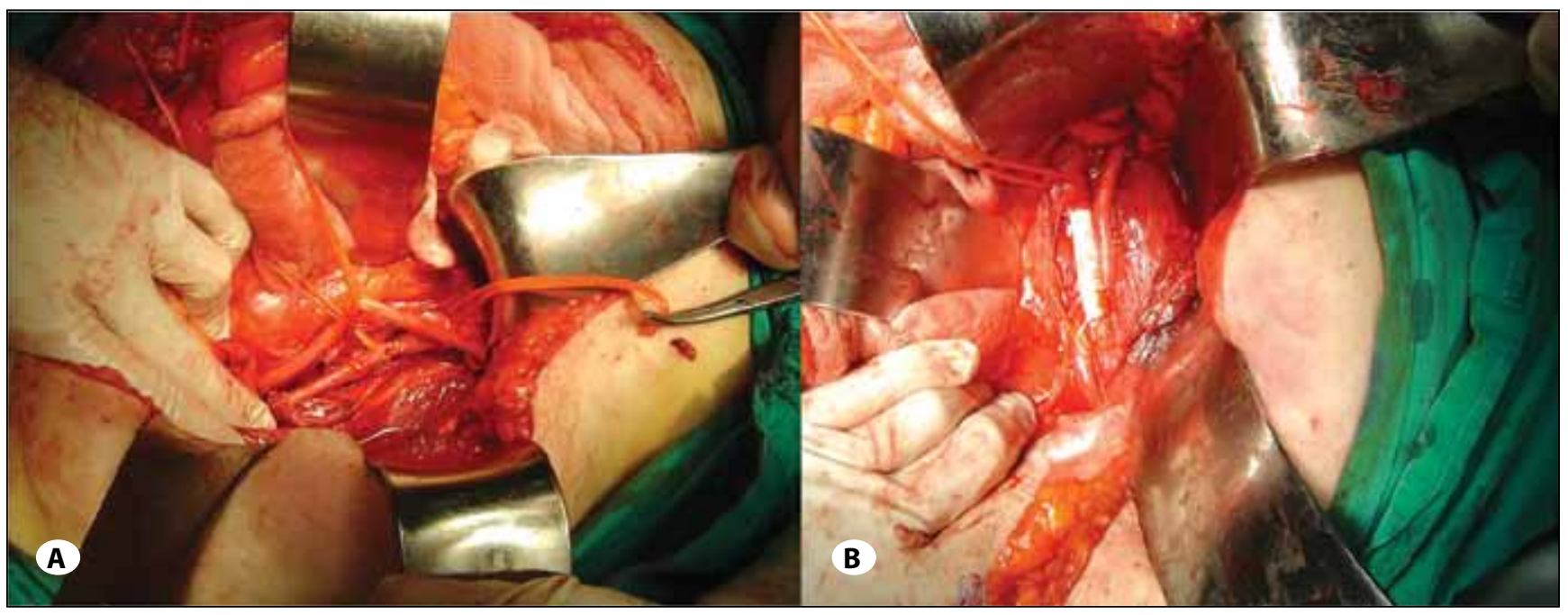

Figure 2: A) Injuried left common iliac artery, B) Reconstructed with PTFE graft. 
lumbar pain due to pseudoaneurysm (PA), bruits and trills on abdominal auscultation, heart failure, lower extremity edema and walking defects in the late period $(3,4,5,9,12,18)$. First two cases were consulted for hypovolemic shock, and third one was consulted for lower limb ischemia at the early period of the operation.

Diagnosis can be made by physical examination or emergency laparotomy on instable patients (development of hemorrhagic shock), or even in autopsy; but in hemodynamically stable patients, duplex ultrasound, computerized tomography (CT), and CT angiography can be used to determine the injury and the level of the vascular disruption $(3,9,12,13,18)$. Conventional angiography can be used for both diagnostic and therapeutic measures $(7,16,17,20)$. First case was in shock and diagnosed by emergency laparotomy, second one by CT angiography and third one was diagnosed by simply the physical examination. It is important to keep in mind that hypovolemic shock at early postoperative period of lumbar discectomy should raise major vascular injury suspicion. Under these circumstances, early repair of injury is life saving. Peroperative mortality because of hemorrhagic shock ranges about $15 \%$, and reaches $100 \%$ at delayed cases $(4,12,13)$. Our first patient deceased because of disseminated intravascular coagulation due to massive blood transfusion, but the others were discharged without any problem. In patients who were operated for AVF or PA on the late period, mortality risk is about $5 \%$ or lower $(1,6,8,12)$.

The level of lumbar surgery effects the localization of vascular injury. L4-L5 level is the most common site for discectomy, so vascular injury is especially seen at common iliac artery and vein. Injury on aortic bifurcation or inferior vena cava can be seen during the surgery of more proximal levels then L4-L5 $(3,12,13,14,17,18)$. In all these three patients, L4-L5 discectomy was performed previously. Common iliac artery and vein injuries were seen in all of them compatible with the literature.

There are various treatment options depending on the injured vessel and the type of injury. In the case of an arterial injury, all alternatives must be utilized to provide the continuity of the vascular structure to protect the extremity. Primary repair, graft interposition, synthetic or saphenous vein patch plasty, or endovascular interventions are the treatment options for arterial injury $(3,4,7,9,11,12,13,16,17,18)$. Primary repair was performed in our two patients, and in one we performed synthetic polytetrafluoroethylene graft interposition for complicated major arterial injury. In the case of a major venous injury, venous ligation should be performed to save time for the safety of the patient and the early control of hemorrhage, except in minor venous injury (10). In the second patient, we ligated the left iliac vein because of a major injury. However, pulmonary embolus was developed under these circumstances.

In conclusion, iatrogenic vascular injury during lumbar disc surgery is a rare but life or extremity threatening complication.
Progressive hypotension during lumbar disc surgery is an important sign to alert that a major vascular injury might have developed. Physical examination at the postoperative period can lead to a prompt diagnosis. In this condition, even it hasn't been hands on vascular surgery, early laparotomy and control of the hemorrhage (may be with packing) is the life saving and time-gaining step as a bridge to definitive vascular surgery.

\section{REFERENCES}

1. Bingol $\mathrm{H}$,Cingoz $\mathrm{F}$, Yilmaz AT, Yasar $\mathrm{M}$, Tatar $\mathrm{H}$ : Vascular complications related to lumbar disc surgery. J Neurosurg 100:249-253,2004

2. Brewster DC, May AR, Darling RC, Abbott WM, Moncure AC: Variable manifestations of vascular injury during lumbar disk surgery. Arch Surg 114:1026-1030, 1979

3. Chang CP, Lee WS, Lee SC: Left internal iliac artery and vein tear during microendoscopic lumbar discectomy - a case report. Minim Invasive Ther Allied Technol 15:155-158, 2006

4. Dosoglu $M$, Is $M$, Pehlivan M, Yildiz KH: Nightmare of lumbar disc surgery: Iliac artery injury. Clin Neurol Neurosurg 108:174-177, 2006

5. Erkut B, Unlu Y, Kaygin MA, Colak A, Erdem AF: latrogenic vascular injury during to lumbar disc surgery. Acta Neurochir 149: 511-515, 2007

6. Franzini M, Altana P, Annessi V, Lodini V: latrogenic vascular injuries following lumbar disc surgery. Case report and review of the literature. J Cardiovasc Surg (Torino) 28: 727-730, 1987

7. Gallerani M, Maida G, Boari B, Galeotti R, Rocca T, Gasbarro V: High output heart failure due to an iatrogenic arterio-venous fistula after lumbar disc surgery. Acta Neurochir 149: 12431247,2007

8. Goodkin R, Laska LL: Vascular and visceral injuries associated with lumbar disc surgery: Medicolegal implications. Surg Neurol 49: 358-370, 1998

9. Inamasu J, Guiot BH: Vascular injury and complication in neurosurgical spine surgery. Acta Neurochir 148: 375-387, 2006

10. Kurtoglu M, Yanar H, Taviloglu K, Sivrikoz E, Plevin R, Aksoy $M$ : Serious lower extremity venous injury management with ligation: Prospective overview of 63 patients. Am Surg 73: 1039-1043, 2007

11. Langmayr JJ, Kofler A, Buchberger W: Retroperitoneal vascular injuries as a complication of lumbar disc operation. Wien Klin Wochenschr 105: 144-146, 1993

12. Papadoulas S, Konstantinou D, Kourea HP, Kritikos N, Haftouras N, Tsolakis JA: Vascular injury complicating lumbar disc surgery. A systematic review. Eur J Vasc Endovasc Surg 24: 189-195, 2002

13. Prabhakar H, Bithal PK, Dash M, Chaturvedi A: Rupture of aorta and inferior vena cava during lumbar disc surgery. Acta Neurochir 147: 327-329, 2005

14. Quigley TM, Stoney RJ: Arteriovenous fistulas following lumbar laminectomy: The anatomy defined. J Vasc Surg 2: 828-833, 1985 
15. Salvador A Brau, Delamarter RB, Schiffman ML, Williams LA, Watkins RG: Vascular injury during anterior lumbar surgery. Spine Journal 4: 409-412, 2004

16. Skippage P, Raja J, McFarland R, Belli AM: Endovascular repair of iliac artery injury complicating lumbar disc surgery. Eur Spine J 17: 228-231, 2008

17. Smith DW, Lawrence BD: Vascular complications of lumbar decompression laminectomy and foraminotomy. A unique case and review of the literature. Spine 16: 387-390, 1991
18. Szolar DH, Preidler KW, Steiner H, Riepl T, Flaschka G, Stiskal M, Moelleken S, Norman D: Vascular complications in lumbar disk surgery: Report of four cases. Neuroradiology 38:521525,1996

19. Torun $F$, Tuna $H$, Deda $H$ : Abdominal vascular injury during lumbar disc surgery: Report of three cases. Ulus Travma Acil Cerrahi Derg 13: 165-167, 2007

20. Tsai YD, Yu PC, Lee TC, Chen HS, Wang SH, Kuo YL: Superior rectal artery injury following lumbar disc surgery. Case report. J Neurosurg 95: 108-110, 2001 